\title{
Pengaruh Dana Alokasi Umum (DAU) dan Pendapatan Asli Daerah (PAD) terhadap Belanja Daerah di Provinsi Kalimantan Barat
}

\author{
Sari Rusmita* \\ Universitas Tanjungpura
}

\begin{abstract}
The local government can take over their support of various factors resources that can drive the wheels of government organizations in order to achieve objectives. Local Government Expenditure is expected to meet the needs of terrain is through the PAD, as well as other sources of revenue. This study uses secondary data obtained from the Central Statistics Agency of West Kalimantan Year 2009-2014, namely in the form of DAU, PAD, and Expenditure in West Kalimantan. The results showed that the F test between DAU and PAD together a significant influence on regional spending is shown on the $F$ count $(3,598)>F$ table $(3.032)$, at a significance level of 0.033 under significance level $0,05(0.033<0.05)$.
\end{abstract}

Keywords : DAU, PAD, Expenditure

\section{PENDAHULUAN}

Pesatnya pembangunan daerah yang menyangkut perkembangan kegiatan fiskal yang membutuhkan alokasi dana dari pemerintah daerah mengakibatkan pembiayaan pada pos belanja yang terdiri dari pengeluaran rutin dan pengeluaran pembangunan membutuhkan tersedianya dana yang besar untuk membiayai kegiatan tersebut. Belanja (pengeluaran) pemerintah daerah yang oleh pemerintah daerah dilaporkan dalam APBD merupakan kegiatan rutin pengeluaran kas daerah untuk membiayai kegiatan-kegiatan operasi dalam pemerintahan. Dengan belanja yang semakin meningkat, maka dibutuhkan dana yang besar pula agar belanja untuk kebutuhan pemerintah daerah dapat terpenuhi. Dengan terpenuhinya kebutuhan belanja pemerintah, maka diharapkan pelayanan terhadap masyarakat menjadi lebih baik dan kesejahteraan masyarakat menjadi meningkat.

\footnotetext{
Korespondensi : Sari Rusmita, Jurusan Akuntansi, Fakultas Ekonomi dan Bisnis, Universitas Tanjungpura, Jl. Prof. Dr. H. Hadari Nawawi, Pontianak 78124, Indonesia. E-mail : sari_rusmita@yahoo.com.
} 
Belanja daerah merupakan pengalokasian dana yang harus dilakukan secara efektif dan efisien, dimana belanja daerah dapat menjadi tolak ukur keberhasilan pelaksanaan kewenangan daerah. Apalagi dengan adanya otonomi daerah, pemerintah dituntut untuk mengelola keuangan daerah secara baik dan efektif. Fenomena umum yang dihadapi oleh sebagian besar pemerintahan daerah di bidang keuangan daerah adalah relatif kecilnya peranan (kontribusi) PAD di dalam struktur Anggaran Pendapatan dan Belanja Daerah (APBD). Dengan kata lain peranan/kotribusi penerimaan yang berasal dari pemerintah pusat dalam bentuk sumbangan dan bantuan, bagi hasil pajak dan bukan pajak, mendominasi susunan APBD.

Berlakunya Undang-Undang No.33 Tahun 2004 tentang perimbangan keuangan pusat dan daerah, membawa perubahan mendasar pada sistem dan mekanisme pengelolaan pemerintah daerah. UU ini menegaskan bahwa untuk pelaksanaan kewenangan pemerintah daerah, pemerintahan pusat akan mentransferkan dana perimbangan kepada pemerintah daerah. Dana perimbangan tersebut terdiri dari Dana Alokasi Umum (DAU), Dana Alokasi Khusus (DAK), dan bagian daerah dari bagi hasil pajak pusat. Disamping dana perimbangan tersebut, pemerintah daerah juga memiliki sumber pendanaan sendiri berupa Pendapatan Asli Daerah (PAD), pinjaman daerah, maupun lain-lain penerimaan daerah yang sah. Kebijakan penggunaan semua dana tersebut diserahkan kepada pemerintah daerah.

Tujuan dari transfer dana perimbangan kepada pemerintah daerah adalah untuk mengurangi kesenjangan fiskal antara pemerintah dan menjamin tercapainya standar pelayanan publik. Adanya transfer dana ini bagi pemerintah daerah merupakan sumber pendanaan dalam melaksanakan kewenangannya, sedangkan kekurangan pendanaan diharapkan dapat digali melalui sumber pendanaan sendiri yaitu PAD. Namun kenyataannya, transfer dari pemerintah pusat merupakan sumber dana utama pemerintah daerah untuk membiayai operasi utamanya sehari-hari atau belanja daerah, yang oleh pemerintah daerah dilaporkan diperhitungkan dalam APBD. Harapan pemerintah pusat dana transfer tersebut dapat digunakan secara efektif dan efisien oleh pemerintah daerah untuk meningkatkan pelayanaan kepada masyarakat. Kebijakan penggunaan dana tersebut sudah seharusnya pula dilakukan secara transparan dan akuntabel.

Pendapatan asli daerah (PAD) Kalimantan Barat terdiri dari pajak daerah, retribusi daerah, hasil pengelolaan kekayaan daerah yang dipisahkan, dan pendapatan lain-lain sebagaimana diterangkan pada Tabel 1. Realisasi pendapatan daerah provinsi Kalimantan Barat selama tahun 2012 hingga 2015 berdasarkan data perkembangan realisasi penerimaan daerah, menunjukkan bahwa sumber penerimaan asli daerah (PAD) yang berasal dari sektor pajak daerah masih merupakan sumber yang paling besar, sedangkan penerimaan yang berasal dari retribusi daerah pada beberapa periode menempati urutan kedua. Hal ini menunjukkan bahwa pajak daerah dan retribusi daerah masih memegang peranan penting bagi sumber utama pendapatan 
daerah. Dengan besarnya PAD yang diperoleh provinsi Kalimantan Barat secara khusus pada tahun 2012 hingga 2015, menunjukkan adanya tren kenaikan penerimaan daerah. Hal ini cukup ideal dengan semangat otonomi daerah yang semakin berkembang.

Tabel 1. Sumber Pendapatan Asli Daerah (PAD) Kalimantan Barat Tahun 2012 - 2015 (dalam juta rupiah)

\begin{tabular}{clcccc}
\hline \multirow{2}{*}{ No } & \multirow{2}{*}{ Pendapatan Asli Daerah } & \multicolumn{4}{c}{ Tahun } \\
\cline { 3 - 6 } & & $\mathbf{2 0 1 2}$ & $\mathbf{2 0 1 3}$ & $\mathbf{2 0 1 4}$ & $\mathbf{2 0 1 5}$ \\
\hline 1 & Pajak daerah & 986.813 & 1.129 .549 & 1.343 .346 & 1.459 .364 \\
2 & Retribusi daerah & 89.055 & 108.076 & 166.639 & 120.979 \\
3 & Hasil pengelolaan kekayaan & 47.620 & 55.010 & 62.865 & 66.063 \\
& daerah yang dipisahkan & & & & 56.135 \\
4 & pendapatan lain-lain & 40.936 & 54.760 & 48.759 & 1.702 .541 \\
\hline
\end{tabular}

Sumber Data : BPS Kalbar, 2016

Tabel 2. Target dan Realisasi Pendapatan Asli Daerah Kalimantan Barat Tahun 2012 - 2015

\begin{tabular}{cccc}
\hline Tahun & $\begin{array}{c}\text { Target } \\
\text { (Juta Rp) }\end{array}$ & $\begin{array}{c}\text { Realisasi } \\
\text { (Juta Rp) }\end{array}$ & $\begin{array}{c}\text { Pemenuhan } \\
(\%)\end{array}$ \\
\hline 2012 & 1.167 .994 & 1.164 .425 & 99,69 \\
2013 & 1.376 .087 & 1.347 .396 & 97,91 \\
2014 & 1.664 .104 & 1.621 .610 & 97,44 \\
2015 & 1.900 .842 & 1.702 .542 & 89,57 \\
\hline
\end{tabular}

Sumber Data : BPS Kalbar, 2016

Namun demikian dengan melihat paparan pada Tabel 2 menunjukkan bahwa pendapatan asli daerah (PAD) Kalimantan Barat tahun 2012 - 2015 tidak dapat melampaui target yang ditetapkan. Hal ini nampaknya memberikan hasil yang kontradiktif dengan semangat otonomi daerah yang semakin berkembang pada dewasa ini.

Melihat tren dan fenomena tersebut, pemerintah daerah Kalimantan Barat sewajarnya mulai memikirkan dan bertindak guna menggali potensi penerimaan daerah yang lain. Hal ini sesuai dengan Undang-Undang No 34 Tahun 2000 yang merupakan perubahan atas Undang-Undang No 18 Tahun 1987 tentang Pajak Daerah dan Retribusi Daerah, yang memberikan peluang dalam menggali potensi sumber-sumber keuangannya termasuk obyek pajak baru dengan catatan sepanjang memenuhi kriteria yang telah ditetapkan dan sesuai dengan aspirasi masyarakat. Tindakan ini merupakan sebuah konsekuensi atas ditetapkannya Undang-Undang mengenai otonomi daerah yang menyebabkan pemerintah daerah harus dapat mengurangi ketergantungan anggaran dari pemerintah pusat dalam bentuk DAU.

Peneliti sebelumnya Maemunah (2006) yang meneliti di Sumatera Utara 
memperoleh hasil yaitu PAD kurang signifikan berpengaruh terhadap Belanja Daerah. Hal tersebut berarti terjadi flypaper effect. Hal ini sesuai hipotesisnya yang menyatakan pengaruh DAU terhadap Belanja Daerah lebih besar daripada pengaruh PAD terhadap Belanja Daerah yang diterima. Oleh karena itu, untuk mengetahui ada tidaknya pengaruh dari DAU dan PAD terhadap Belanja Daerah Kabupaten/Kota di Provinsi Kalimantan Barat, maka diperlukan penelitian yang lebih dalam untuk membahas hal tersebut.

\section{TINJAUAN PUSTAKA}

\subsection{Hubungan Keuangan Pusat-Daerah}

Menurut pendapat Mardiasmo (2004 : 58), keuangan negara merupakan bagian dari ilmu ekonomi yang mempelajari tentang kegiatan-kegiatan pemerintah di dalam bidang ekonomi, terutama mengenai penerimaan dan pengeluarannya serta pengaruhnya di dalam perekonomian. Tujuan suatu kerangka hubungan keuangan pusat-daerah adalah untuk menjelaskan tiga hal pokok, yaitu: pembagian kekuasaan tingkat-tingkat pemerintahan dalam memungut dan membelanjakan sumber dan dana pemerintahan yakni pembagian yang sesuai dengan pola umum desentralisasi, pembagian yang memadai dari sumber-sumber dana secara keseluruhan untuk membiayai pelaksanaan fungsi-fungsi, penyediaan pelayanan dan pelaksanaan pembangunan yang diselenggarakan oleh pemerintah negara, dan distribusi pengeluaran pemerintah secara merata di antara daerah satu dan daerah lainnya.

Pola pembiayaan terhadap wewenang yang dilimpahkan oleh pusat kepada daerah sebagian besar diperoleh dari pendapatan asli daerah. Namun kenyataannya dominasi pusat masih terlalu kuat bagi daerah di dalam pembiayaan pembangunan daerah. Salah satu bentuknya adalah dengan pemberian sumber dana yang berkaitan dengan wewenang yang diberikan. Dalam rangka menyelenggarakan pemerintahan dan melaksanakan fungsi pelayanan publik di daerah, pemerintah membutuhkan anggaran sebanding dengan kegiatan yang harus dijalankan. Kebutuhan keuangan daerah dapat diperoleh dari Pendapatan Asli Daerah dan bantuan atau subsidi dari pemerintah pusat.

\subsection{Dana Alokasi Umum (DAU)}

Dana Alokasi Umum adalah dana yang berasal dari APBN yang dialokasikan dengan tujuan pemerataan kemampuan keuangan antar daerah untuk membiayai kebutuhan pembelanjaan. Dana alokasi umum merupakan bantuan dan pemerintah pusat kepada pemerintah daerah melalui transfer untuk membantu keuangan daerah (PP No.104 Tahun 2000, pasal 15).

Dalam konsep anggaran berimbang, Pemda diharuskan menyerahkan anggarannya 
kepada legislatif sebelum tahun fiskal berjalan, tetapi tidak mengatur bagaimana pengeluaran harus diprioritaskan atau bagaimana komponen-komponen pengeluaran ditentukan. Oleh karena itu, Pemda dapat melakukan smoothing atas pengeluaranpengeluarannya karena memang tidak ada aturan yang secara efektif digunakan untuk mencegahnya.

\subsection{Pendapatan Asli Daerah (PAD)}

Penerimaan Pendapatan Asli Daerah merupakan akumulasi dari Pos Penerimaan Pajak yang berisi Pajak Daerah dan Pos Retribusi Daerah, Pos Penerimaan Non Pajak yang berisi hasil perusahaan milik daerah, Pos Penerimaan Investasi serta Pengelolaan Sumber Daya Alam.

Pendapatan Asli Daerah (PAD) merupakan semua penerimaan daerah yang berasal dari sumber ekonomi asli daerah. Menurut Elita Dewi, dalam Maemunah (2006) yang membahas tentang identifikasi sumber pendapatan daerah, dijelaskan bahwa identifikasi adalah pengenalan atau pembuktian sama. Jadi identifikasi sumber pendapatan asli daerah adalah meneliti, menentukan dan menetapkan mana sesungguhnya yang menjadi sumber pendapatan asli daerah dengan cara meneliti dan mengusahakan serta mengelola sumber pendapatan tersebut dengan benar sehingga memberikan hasil yang maksimal.

\subsection{Belanja Daerah}

Belanja daerah adalah semua pengeluaran kas daerah dalam periode tahun bersangkutan yang mengurangi kekayaan pemerintah daerah. Dalam struktur anggaran daerah dengan pendekatan kinerja, pengeluaran daerah dirinci menurut organisasi, fungsi, kelompok dan jenis belanja.

Belanja daerah menurut organisasi adalah suatu kesatuan penggunaan seperti sekretariat daerah, dinas daerah, dan lembaga teknis daerah lainnya. Fungsi belanja misalnya pendidikan, kesehatan dan fungsi-fungsi lainnya. Kelompok belanja misalnya belanja administrasi umum, belanja operasi dan biaya pemeliharaan serta belanja investasi. Jenis belanja misalnya belanja pegawai, belanja barang, belanja perjalanan dinas, dan belanja lain-lain. Belanja daerah dibagi menjadi belanja rutin, belanja investasi, pengeluaran transfer dan pengeluaran tidak tersangka.

\subsection{Pengaruh DAU terhadap Belanja Daerah}

Dalam literatur ekonomi dan keuangan daerah, hubungan pendapatan dan belanja daerah didiskusikan secara luas sejak akhir dekade 1950-an dapat dirumuskan dengan 
rumus sebagai berikut :

$$
\mathrm{Y}=\mathrm{C}+\mathrm{I}+\mathrm{S}
$$

Notasi Y dalam rumus di atas adalah merupakan pendapatan dalam penelitian ini adalah PAD dan DAU, sedangkan $\mathrm{C}$ adalah belanja daerah. Oleh karena itu apabila PAD dan DAU naik maka belanja daerah juga akan mengalami peningkatan.

Sebagian studi menyatakan bahwa pendapatan mempengaruhi belanja, sementara sebagian lainnya menyatakan bahwa belanjalah yang mempengaruhi pendapatan (Aziz, 2000; Doi, 1998 dalam Abdullah \& Halim, 2003). Sementara studi tentang pengaruh transfer atau grants dari Pempus terhadap keputusan pengeluaran atau belanja Pemda sudah berjalan lebih dan 30 tahun (Gamkar \& Oates, 1996 dalam Abdullah \& Halim, 2003). Secara teoritis, respon tersebut akan mempunyai efek distributif dan alokatif yang tidak berbeda dengan sumber pendanaan lain, misalnya pendapatan pajak daerah (Bradford \& Oates, 1971a dalam Abdullah \& Halim, 2003). Namun, dalam studi empiris hal tersebut tidak selalu terjadi. Artinya, stimulus terhadap pengeluaran daerah yang ditimbulkan oleh transfer atau grants tersebut sering lebih besar dibandingkan dengan stimulus dari pendapatan (pajak) daerah sendiri.

\subsection{Pengaruh PAD terhadap Belanja Daerah}

Studi tentang pengaruh pendapatan daerah (local own source revenue) terhadap pengeluaran daerah sudah banyak dilakukan (Misalnya, Blackly, 1986; Joulfain \& Mokeerjee, 1990; Legrenzi \& Milas, 2001; Von Frustenberg et al, 1986 dalam Abdullah \& Halim, 2003). Hipotesis yang menyatakan bahwa pendapatan daerah akan mempengaruhi anggaran belanja pemerintah daerah dikenal dengan nama tax-spend hypotesis. Dalam hal ini, pengeluaran pemerintah daerah akan disesuaikan dengan perubahan dalam penerimaan pemerintah daerah atau perubahan pendapatan terjadi sebelum perubahan pengeluaran.

Dalam konteks internasional, beberapa penelitian yang telah dilakukan untuk melihat pengaruh pendapatan daerah terhadap belanja ( di antaranya adalah Cheng,1999; Friedman, 1978; Hoover \& Shefluin, 1992 dalam Abdullah \& Halim, 2003), Chang (1999) menemukan bahwa hipotesis pajak-belanja berlaku untuk kasus Pemda di beberapa negara. Friedman (1978) dalam Abdullah \& Halim (2003) menyatakan bahwa kenaikan dalam pajak akan meningkatkan belanja daerah, sehingga akhirnya akan memperbesar defisit. Hoover \& Sheffrin (1992) dalam Abdullah \& Halim (2003) secara empiris menemukan adanya perbedaan hubungan dalam dua rentang waktu berbeda. Mereka menemukan bahwa untuk sampel data sebelum pertengahan tahun 1960-an pajak berpengaruh terhadap belanja, sementara untuk sampel data sesudah tahun 1960-an pendapatan daerah dan belanja tidak saling mempengaruhi (causally 
independent).

\section{METODE PENELITIAN}

\subsection{Populasi dan Sampel}

Populasi adalah jumlah dari keseluruhan obyek-obyek (satuan/individu) yang mempunyai karakteristik tertentu. Adapun populasi dalam penelitian ini adalah data DAU, PAD, Belanja Daerah Kota dan 14 Kabupaten/Kota di Provinsi Kalimantan Barat yang meliputi 12 daerah Kabupaten dan 2 daerah Kota sehingga daerah total populasi adalah 14 data.

Sampel adalah bagian dari populasi yang mempunyai karakteristik dianggap dapat mewakili keseluruhan populasi. Teknik sampling yang digunakan adalah teknik full sampling, yaitu semua populasi digunakan sebagai sampel. Penelitian ini mengambil data pada tahun 2009-2014, dengan jumlah sampel sebanyak 14 daerah, maka jumlah sampel penelitian keseluruhan menjadi $3 \times 14$ x $6=252$ data.

\subsection{Jenis data}

Data yang digunakan dalam penelitian ini adalah data sekunder. Data sekunder merupakan sumber data penelitian yang diperoleh peneliti secara tidak langsung melalui media perantara (diperoleh dan dicatat oleh pihak lain). Data sekunder yang digunakan adalah Dana Alokasi Umum, Pendapatan Asli Daerah dan Belanja Daerah Kabupaten/Kota di Kalimantan Barat tahun 2009-2014.

\subsection{Variabel Penelitian dan Definisi Operasional}

Variabel - variabel yang digunakan dalam studi ini adalah :

1. Variabel Independen

a. Dana Alokasi Umum (DAU) adalah dana yang bersumber dari pendapatan APBN yang dialokasikan dengan tujuan pemerataan kemampuan keuangan antar daerah untuk mendanai kebutuhan daerah dalam rangka pelaksanaan Desentralisasi (UU Nomor 33 Tahun 2004).

b. Pendapatan Asli Daerah (PAD) adalah pendapatan yang diperoleh daerah yang dipungut berdasarkan Peraturan Daerah sesuai dengan peraturan perundangundangan (UU Nomor 32 Tahun 2004).

2. Variabel dependen

Belanja Daerah adalah semua kewajiban daerah yang diakui sebagai pengurang 
nilai kekayaan bersih dalam periode tahun anggaran yang bersangkutan (UU No. 32 Tahun 2004).

\subsection{Teknik Analisis Data}

Teknik analisis data yang digunakan dalain penelitian ini adalah:

1. Analisis kualitatif, yaitu metode yang digunakan untuk menganalisis data dengan menjelaskan secara rinci tentang dana alokasi umum dan pendapatan asli daerah, belanja daerah.

2. Analisis kuantitatif yaitu metode yang digunakan untuk menganalisis data yang berhubungan dengan masalah pengaruh dana alokasi umum dan pendapatan asli daerah terhadap belanja daerah dengan cara perhitungan matematis dan angkaangka statistik. Analisis yang digunakan adalah analisis regresi berganda. Analisis ini digunakan untuk mengetahui besarnya variabel independen terhadap variabel dependen, dengan asumsi variabel yang lain konstan, dimana rumusnya:

$$
\mathrm{BD}=\mathrm{b}_{0}+\mathrm{b}_{1} \mathrm{DAU}+\mathrm{b}_{2} \mathrm{PAD}+\ldots+\mathrm{e}
$$

dimana :

$\mathrm{BD}=$ Belanja daerah

DAU = Dana alokasi umum

PAD = Pendapatan asli daerah

a $\quad=$ Konstanta regresi

$\mathrm{b}_{1}, \mathrm{~b}_{2} \quad=$ Koefisien regresi

\section{TEMUAN DAN PEMBAHASAN}

\subsection{Deskripsi Objek Penelitian}

Objek dari penelitian ini adalah pemerintah Kabupaten dan Kota di Provinsi Kalimantan Barat. Jumlah pemerintah daerah di provinsi Kalimantan Barat berjumlah 12 pemerintah kabupaten dan 2 pemerintah kota. Provinsi Kalimantan Barat merupakan salah satu provinsi di Indonesia yang berbatasan langsung dengan negara asing, yaitu Negara Bagian Sarawak Malaysia Timur.

Kalimantan Barat memiliki empat kabupaten yang berada di sebelah utara berhadapan langsung dengan negara asing, yaitu Kabupaten Sambas, Kabupaten Sanggau, Kabupaten Sintang dan Kabupaten Kapuas Hulu. Dengan posisi ini, daerah Kalimantan Barat mempunyai akses langsung melalui jalan darat untuk keluar masuk negara asing tersebut. 
Pemerintah Kabupaten dan Kota di Provinsi Kalimantan Barat yang menjadi objek dalam penelitian ini adalah berjumlah 12 pemerintah kabupaten dan 2 pemerintah kota, yaitu sebagai berikut :

1. Kabupaten Sambas

2. Kabupaten Bengkayang

3. Kabupaten Landak

4. Kabupaten Pontianak

5. Kabupaten Sanggau

6. Kabupaten Ketapang

7. Kabupaten Sintang
8. Kabupaten Kapuas Hulu

9. Kabupaten Sekadau

10. Kabupaten Melawi

11. Kabupaten Kayong Utara

12. Kabupaten Kubu Raya

13. Kota Pontianak

14. Kota Singkawang

Tabel 3. Jumlah Penduduk Pada Kabupaten/Kota Provinsi Kalimantan Barat Tahun 2009- 2015

\begin{tabular}{lrrrrrrr}
\hline \multirow{2}{*}{ Kabupaten/Kota } & \multicolumn{7}{c}{ Tahun } \\
\cline { 2 - 7 } & \multicolumn{1}{c}{$\mathbf{2 0 0 9}$} & $\mathbf{2 0 1 0}$ & $\mathbf{2 0 1 1}$ & $\mathbf{2 0 1 2}$ & $\mathbf{2 0 1 3}$ & $\mathbf{2 0 1 4}$ & $\mathbf{2 0 1 5}$ \\
\hline Sambas & 496.464 & 496.120 & 501.149 & 505.444 & 515.571 & 519.887 & 523.115 \\
Bengkayang & 209.927 & 215.277 & 220.067 & 224.407 & 228.771 & 232.873 & 238.610 \\
Landak & 331.171 & 329.649 & 335.452 & 340.635 & 347.504 & 352.897 & 357.608 \\
Mempawah & 220.231 & 234.021 & 237.722 & 241.003 & 245.924 & 249.521 & 251.775 \\
Sanggau & 395.061 & 408.468 & 415.955 & 422.658 & 431.175 & 438.994 & 444.596 \\
Ketapang & 471.974 & 427.460 & 437.613 & 446.849 & 455.751 & 464.227 & 475.985 \\
Sintang & 373.380 & 364.759 & 371.322 & 377.190 & 384.692 & 390.796 & 396.392 \\
Kapuas Hulu & 222.893 & 222.160 & 227.067 & 231.512 & 236.136 & 240.410 & 245.998 \\
Sekadau & 180.649 & 181.634 & 184.103 & 186.266 & 190.048 & 191.797 & 193.391 \\
Melawi & 171.362 & 178.645 & 182.225 & 185.449 & 189.061 & 192.301 & 195.999 \\
Kayong Utara & 92.382 & 95.594 & 97.643 & 99.495 & 101.529 & 103.282 & 105.477 \\
Kubu Raya & 502.845 & 500.970 & 510.373 & 518.803 & 529.320 & 538.815 & 545.409 \\
Kota Pontianak & 527.102 & 554.764 & 565.856 & 575.843 & 587.169 & 598.097 & 607.618 \\
Kota Singkawang & 177.701 & 186.462 & 190.801 & 194.743 & 198.742 & 202.196 & 207.601 \\
Kalimantan Barat & 4.319 .142 & 4.395 .983 & 4.477 .348 & 4.550 .297 & 4.641 .393 & 4.716 .093 & 4.789 .574 \\
\hline
\end{tabular}

Sumber: Kalimantan Barat Dalam Angka 2009 - 2016, BPS

Kondisi jumlah penduduk di wilayah Provinsi Kalimantan Barat dari tahun ke tahun dari tahun 2009 s/d 2016 mengalami kenaikan. Tahun 2009 jumlah penduduk di wilayah Kalimantan Barat sebanyak 4.319.142 jiwa, tahun 2010 jumlah penduduk di wilayah Kalimantan Barat meningkat sebesar 1,78\% dari tahun 2009 yaitu sebanyak 4.395.983 jiwa. Jumlah penduduk wilayah Kalimantan Barat pada tahun 2011 dan 2012 masing-masing sebanyak 4.477.348 jiwa dan 4.550.297 jiwa yang artinya pada dua tahun tersebut pun mengalami kenaikan dari tahun sebelumnya yang masing-masing mengalami kenaikan sebesar 1,85\% dan 1,63\%. Demikian pula untuk tahun 2013 dan 2014 jumlah penduduk juga mengalami pertambahan yaitu masing-masing sebesar 4.641.393 jiwa dan 4.716.093 jiwa, yang berarti pada masing-masing tahun meningkat sebesar $2 \%$ dan $1,61 \%$.

Jumlah penduduk di wilayah Provinsi Kalimantan Barat tahun 2015 sebanyak 4.789.574 jiwa dengan tingkat kepadatan penduduk 33 jiwa per $\mathrm{km}^{2}$ mengalami 
pertambahan penduduk sebesar 1,55\%. Kabupaten/Kota yang paling banyak menyumbang jumlah penduduk adalah Kota Pontianak yang mana pada tahun 2015 jumlah penduduk Kota Pontianak sebesar 607.618 jiwa yang kemudian diikuti oleh Kabupaten Kubu Raya yang memiliki jumlah penduduk sebanyak 545.409 jiwa. Sedangkan jumlah penduduk yang paling sedikit dimiliki oleh Kabupaten Kayong Utara yaitu sebesar 105.477 jiwa. Secara lengkap dapat dilihat pada Tabel 3 jumlah penduduk di wilayah Kalimantan Barat dari tahun 2009 s/d 2014. Dalam tabel tersebut dapat terlihat jelas kondisi daerah yang memiliki jumlah penduduk yang tertinggi, sedang dan terendah. Berikut ini adalah gambar yang menunjukkan jumlah penduduk miskin dan garis kemiskinan di Provinsi Kalimantan Barat.

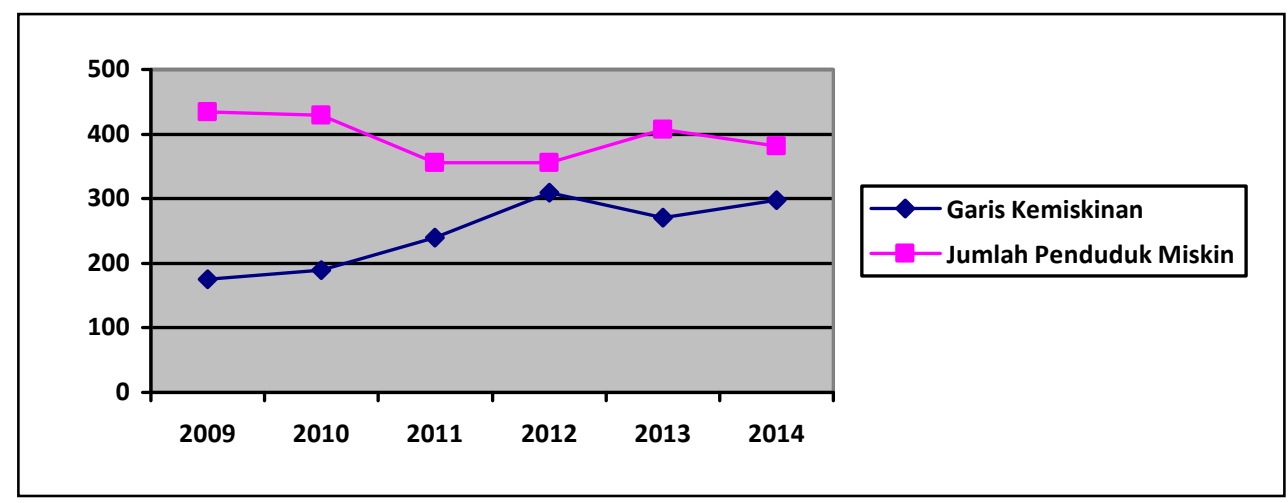

Gambar 1. Garis Kemiskinan dan Jumlah Penduduk Miskin Provinsi Kalimantan Barat Tahun 2009- 2014

Garis kemiskinan di wilayah Provinsi Kalimantan Barat dari tahun ke tahun terus mengalami perubahan, pada tahun 2009 garis kemiskinannya adalah 174.617 Rp/Kapita/Bulan dengan jumlah penduduk miskin sebanyak 434.770 jiwa. Garis kemiskinan pada tahun 2010 adalah 189.407 Rp/Kapita/Bulan dengan jumlah penduduk miskin sebanyak 428.760 jiwa. Sedangkan pada tahun 2011 dan 2012 masing-masing garis kemiskinannya menunjukkan sebesar $239.162 \mathrm{Rp} / \mathrm{Kapita/Bulan}$ dan 309.567 Rp/Kapita/Bulan. Pada tahun 2013 dan 2014 garis kemiskinan di wilayah Kalimantan Barat sebesar 270.306 Rp/Kapita/Bulan dan 298.212 Rp/Kapita/Bulan.

Seperti yang terlihat pada Gambar 1, jumlah penduduk miskin di wilayah Kalimantan Barat pada tahun 2009 s.d 2014 dapat dilihat bahwa pada tahun 2009 jumlah penduduk miskin lebih banyak ditimbang jumlah penduduk miskin pada tahun-tahun berikutnya. Ini bisa dilihat dari garis kemiskinan lebih kecil dari tahun-tahun berikutnya. Gambar 1 juga dapat kita lihat pada tahun 2013 jumlah penduduk miskin wilayah Kalimantan Barat sebanyak 407.300 jiwa, jumlah ini mengalami peningkatan dari tahun 2012 yang hanya sebanyak 355.700 jiwa artinya ada kenaikan sebesar 20,13\% pada tahun 2013 dari tahun 2012. Namun pada tahun 2014 sedikit mengalami penurunan dari jumlah penduduk miskin pada tahun 2013 yaitu menurun sebesar 6,23\%. 
Jumlah penduduk yang semakin meningkat dari tahun ke tahun selama 2009 sampai dengan 2015 dan posisi yang yang begitu strategis secara teori harusnya kondisi ekonomi di Provinsi Kalimantan Barat memiliki kondisi baik. Namun hal ini tidak tercermin dari kondisi masyarakat dimana jumlah penduduk miskin di Provinsi Kalimantan Barat mengalami tren meningkat dari tahun ke tahun. Sehingga walaupun letak yang sangat strategis dan peningkatan jumlah penduduk dari tahun ke tahun tidak menunjukkan bahwa kondisi penduduk di Kalimantan Barat berada dalam kondisi sejahtera.

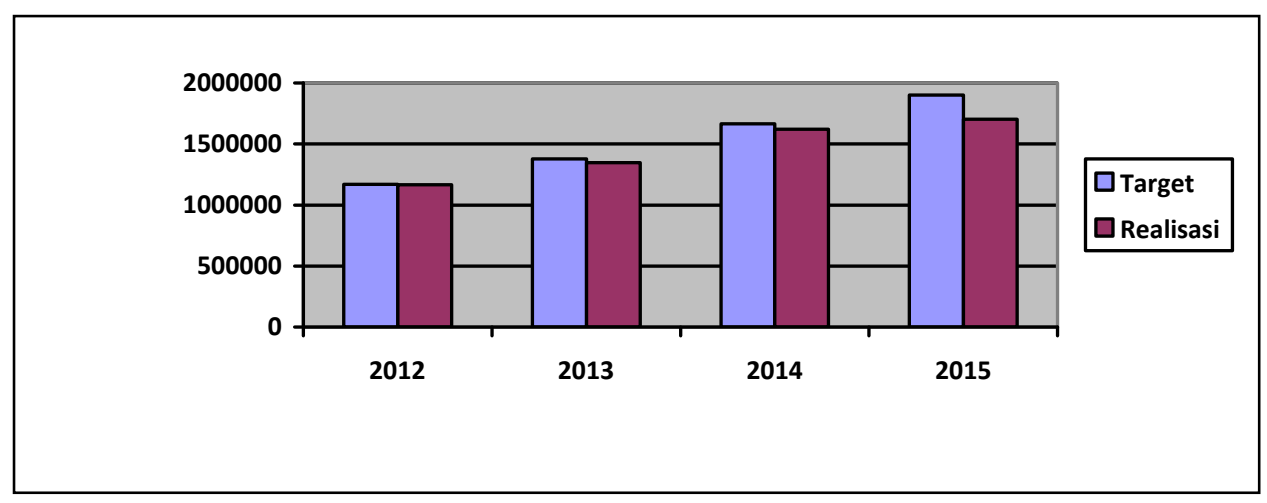

Gambar 2. Target dan Realisasi Pendapatan Asli Daerah Kalimantan Barat Tahun 2012 - 2015

Perlu dilakukan peningkatan kesejahteraan penduduk di provinsi Kalimantan Barat, dan ini sangat perlu peran dari pemerintah daerah dan salah satunya adalah dengan belanja daerah yang dikeluarkan oleh pemerintah daerah yang mendukung dan mendorong peningkatan kesejahteraan masyarakat. Gambar 2 adalah data yang menggambarkan target dan realisasi Pendapatan Asli Daerah di Provinsi Kalimantan Barat untuk tahun 2012 sampai dengan 2015.

Gambar 2 menunjukkan adanya tren kenaikan penerimaan daerah, baik itu dari target maupun realisasi dari Pendapatan Asli Daerah (PAD). Hal ini cukup ideal dengan semangat otonomi daerah yang semakin berkembang. Namun pendapatan asli daerah (PAD) Kalimantan Barat tahun 2012 - 2015 tidak dapat melampaui target yang ditetapkan.

\subsection{Statistik Deskriptif}

Berdasarkan hasil pengumpulan dan pengolahan data sekunder mengenai Dana Alokasi Umum, Pendapatan Asli Daerah dan Belanja Daerah dari kabupaten dan kota di Provinsi Kalimantan Barat tahun 2009 sampai dengan 2015, maka diperoleh hasil statistik deskriptif (tabel 4). Berdasarkan tabel 4 dapat dilihat nilai tertinggi, dan terendah, nilai rata - rata dan standar deviasi dari variabel yang diteliti pada kabupaten/kota di Provinsi Kalimantan Barat pada tahun 2009-2014 dengan jumlah populasi 14 kabupaten/kota. Dana Alokasi Umum (DAU) terendah bernilai Rp 
185.529.469,- terdapat di Kabupaten Pontianak (Mempawah) pada tahun 2009, ini menunjukkan bahwa wilayah yang tidak begitu luas bisa mandiri dalam membiayai pelaksanaan otonomi daerah. Nilai tertinggi DAU bernilai Rp 1.020.384.603,- terdapat di Kabupaten Ketapang pada tahun 2014, ini menunjukkan bahwa Kabupaten Ketapang masih sangat bergantung pada pemerintah pusat. Sedangkan nilai rata-rata dari DAU adalah sebesar Rp 477.634.134,39 yang nilainya lebih besar dari nilai standar deviasi yang sebesar Rp 179.526.172,14 menunjukkan bahwa distribusi data kecenderungannya normal.

Tabel 4. Hasil Statistik Deskriptif

\begin{tabular}{llrrrr}
\hline Variabel & $\mathrm{N}$ & \multicolumn{1}{c}{ Minimum } & \multicolumn{1}{c}{ Maximum } & \multicolumn{1}{c}{ Mean } & \multicolumn{1}{c}{ Std. Deviation } \\
\hline DAU & 84 & 185.529 .469 & 1.020 .384 .603 & $477.634 .134,39$ & $179.526 .172,14$ \\
PAD & 84 & 4.814 .889 & 298.768 .480 & $45.286 .181,04$ & $50.110 .447,50$ \\
BD & 84 & 282.792 .168 & 123.625 .034 .826 & $2.208 .914 .151,51$ & $13.416 .052 .269,91$ \\
\hline
\end{tabular}

Rata-rata Pendapatan Asli Daerah (PAD) bernilai Rp 45.286.181,04 dengan nilai terendah sebesar Rp 4.814.889,-- terdapat di Kabupaten Sekadau pada tahun 2009, yang artinya Kabupaten Sekadau masing sangat tergantung dengan dukungan pemerintahan pusat untuk membiayai belanja daerahnya. Selain itu Kabupaten Sekadau juga diharapkan dapat terus menggali sumber-sumber PAD sendiri secara intensif. Sedangkan nilai PAD yang tertinggi terdapat pada Kota Pontianak pada tahun 2014 yang bernilai sebesar Rp 298.768.480,27 ini berarti Kota Pontianak sudah memiliki kemandirian otonomi daerah dalam membiayai pembangunan daerahnya dibandingkan dengan kabupaten dan kota lainnya yang ada di Provinsi Kalimantan Barat. Nilai standar deviasinya sebesar Rp 50.110.447,50. Dan nilainya lebih besar sedikit dari nilai rata-rata PAD, ini menunjukkan distribusi data kecenderungannya mendekati normal.

Belanja Daerah (BD) nilai terendah sebesar Rp 282.792.168,- terdapat di Kabupaten Sekadau pada tahun 2009 ini dapat disebabkan karena jumlah daerah yang tidak begitu luas dan jumlah penduduk yang sedikit sehingga belanja daerah tidak dapat teralokasikan dengan besar. Nilai tertinggi sebesar Rp123.625.034.826,18 terdapat di Kabupaten Kayong Utara pada tahun 2011, ini bisa disebabkan karena pengalokasian belanja daerah difokuskan pada pembangunan daerah. Sedangkan rata-rata belanja daerah adalah sebesar Rp 2.208.914.151,51 dengan standar deviasinya sebesar Rp 13.416.052.269,91. Ini menunjukkan distribusi data yang tidak normal karena nilai standar deviasi lebih tinggi dari pada nilai rata-rata.

\subsection{Hasil Pengujian Asumsi Klasik}

Uji multikolinearitas bertujuan untuk menguji apakah dalam model regresi ditemukan adanya korelasi antara variabel bebas (independen). Uji multikolinearitas dapat dilaksanakan menggunakan model regresi dan melakukan uji korelasi antar 
variabel independen dengan menggunakan Variance Inflation Factor (VIF). Jika nilai tolerance value di atas 0,05 atau nilai Variance Inflation Factor (VIF) dibawah 5 maka tidak terjadi multikolinearitas (Ghozali, 2006). Hasil uji multikolinearitas pada Tabel 5 berikut :

Tabel 5. Hasil Uji Multikolinearitas

\begin{tabular}{llrr}
\hline \multirow{2}{*}{ Model } & & \multicolumn{2}{c}{ Collinearity Statistics } \\
\cline { 3 - 4 } & & Tolerance & VIF \\
\hline & (Constant) & & \\
& DAU & .730 & 1.371 \\
& PAD & .730 & 1.371 \\
\hline
\end{tabular}

Berdasarkan Tabel 5 di atas terlihat bahwa seluruh variabel independen yaitu DAU dan PAD memiliki nilai Variance Inflation Factor (VIF) di bawah 5 yaitu sebesar 1,371 dengan angka tolerance yang menunjukkan nilai lebih dari 0,05 yaitu sebesar 0,730 maka dapat ditarik kesimpulan bahwa tidak terjadi multikolinearitas yang artinya model yang terbentuk tidak terdapat adanya gelaja multikolinearitas antar variabel independen dalam model regresi.

Autokorelasi dalam penelitian ini menggunakan uji statistik Durbin - Waston (D-W). Menurut Singgih (2000), bila angka D-W diantara -2 sampai +2 berarti tidak terjadi autokorelasi. Menurut Ghozali (2006) uji autokorelasi dilakukan untuk mengidentifikasi apakah terdapat autokorelasi antara error yang terjadi antara periode yang diujikan dalam model regresi. Untuk mengetahui ada tidaknya autokorelasi harus dilihat dari nilai uji $\mathrm{D}-\mathrm{W}$.

Tabel 6. Hasil Uji Autokorelasi

\begin{tabular}{lrrrr}
\hline Model & R & R Square & Adjusted R Square & Durbin-Watson \\
\hline 1 & $.121^{\mathrm{a}}$ & .015 & -.010 & 2.076 \\
\hline a. Predictors: (Constant), PAD, DAU & & \\
b. Dependent Variable: BD & & &
\end{tabular}

Nilai D-W sebesar 2,076 nilai ini akan dibandingkan dengan nilai tabel menggunakan signifikansi 5\%, jumlah sampel 252 (n) dan jumlah variabel independen 2 $(\mathrm{k}=2)$. Nilai D-W 2,076 lebih besar dari batas atas (du) 1,60 dan kurang dari 2,40 (4-du), maka dapat disimpulkan bahwa tidak ada autokorelasi.

\subsection{Hasil Uji Regresi Linier Berganda}

Pengujian pengaruh DAU dan PAD terhadap Belanja Daerah secara bersama-sama menggunakan metode analisis regresi linier berganda. Berdasarkan uji hipotesis yang 
telah dilakukan dengan menggunakan bantuan program SPSS (Statistical Package for Social Sciences) pengaruh variabel independen terhadap variabel dependen secara rinci dapat dilihat pada Tabel. 7 .

Tabel 7. Hasil Regresi Pengaruh DAU dan PAD terhadap Belanja Daerah

\begin{tabular}{|c|c|c|c|c|}
\hline & Model & $\begin{array}{c}\text { Unstandardized } \\
\text { B }\end{array}$ & $\begin{array}{c}\text { Coefficients } \\
\text { Std. Error }\end{array}$ & $\begin{array}{c}\text { Standardized } \\
\text { Coefficients } \\
\text { Beta }\end{array}$ \\
\hline \multirow[t]{3}{*}{1} & (Constant) & $6.430 \mathrm{E} 9$ & $4.284 \mathrm{E} 9$ & \\
\hline & DAU & -8.559 & 9.650 & -.115 \\
\hline & PAD & -2.932 & 34.572 & -.011 \\
\hline
\end{tabular}

a. Dependent Variable: BD

Dari hasil perhitungan statistik seperti yang terlihat pada Tabel 7 maka diperoleh persamaan regresi linear berganda sebagai berikut:

$\mathrm{Y}=6,430-8,559 \mathrm{DAU}-2,932 \mathrm{PAD}+\varepsilon$

Dari persamaan regresi tersebut dapat diketahui bahwa konstanta $(\alpha)$ sebesar 6,430 nilai DAU turun sebesar - 8,559 sedangkan PAD juga turun sebesar - 2,932. Dan jika DAU dan PAD bernilai nol, maka Belanja Daerah akan bernilai sebesar Rp 6,430. Sedangkan jika DAU mengalami kenaikan sebesar Rp 1,- maka Belanja Daerah akan mengalami penurunan sebesar Rp 8,559 dengan asumsi PAD tetap. Koefisien yang bernilai negatif ini menunjukkan hubungan yang negatif atau hubungan yang berlawanan arah antara DAU dengan Belanja Daerah, artinya semakin naik DAU suatu daerah akan mengakibatkan penurunan pada Belanja Daerah.

Demikian juga untuk PAD, karena bernilai koefisien negatif yaitu sebesar -2,932 maka hubungan yang terjadi antara PAD dengan Belanja Daerah adalah hubungan berlawanan arah. Ini dapat dibuktikan dengan jika PAD mengalami kenaikan sebesar Rp1,- maka akan berdampak penurunan terhadap Belanja Daerah sebesar Rp 2,932. Dan artinya jika PAD semakin meningkat maka Belanja Daerah akan mengalami penurunan.

Hasil nilai adjusted $R$-Square dari regresi digunakan untuk mengetahui besarnya Belanja Daerah yang dipengaruhi oleh variabel-variabel bebasnya.

Tabel 8. Hasil Koefisien Determinasi

\begin{tabular}{cccc}
\hline Model & $\mathrm{R}$ & $\mathrm{R}$ Square & Adjusted R Square \\
\hline 1 & $.121^{\mathrm{a}}$ & .015 & .010 \\
\hline
\end{tabular}

a. Predictors: (Constant), PAD, DAU

b. Dependent Variable: BD 
Tabel 8 menunjukkan bahwa koefisien determinasi yang ditunjukkan dari nilai $\mathrm{R}^{2}$ sebesar 0,10 hal ini berarti bahwa $10 \%$ variasi Belanja Daerah dapat dijelaskan oleh variasi dari kedua variabel independen yaitu PAD dan DAU. Sedangkan sisanya (100\% $10 \%=90 \%$ ) dijelaskan oleh variable-variabel lainnya yang berada diluar model dalam penelitian ini.

\subsection{Hasil Pengujian Hipotesis}

Hasil perhitungan penelitian ini bertujuan untuk mengetahui hubungan atau pengaruh DAU dan PAD terhadap variabel terikat Belanja Daerah di kabupaten/kota Provinsi Kalimantan Barat. Adapun hasil perhitungan untuk masing-masing variabel sebagai berikut :

Tabel 9. Hasil Pengujian Hipotesis DAU (X1) dan PAD (X2) Terhadap Belanja Daerah (Y) di Kabupaten/Kota Provinsi Kalimantan Barat

\begin{tabular}{ccccc}
\hline Variabel & t-Statistic & Prob & Hipotesis yang Diterima & Keterangan \\
\hline $\begin{array}{c}\text { DAU Terhadap Belanja } \\
\text { Daerah }\end{array}$ & $-0,887$ & 0,378 & $\mathrm{H}_{0}$ diterima dan $\mathrm{H}_{1}$ ditolak & $\begin{array}{c}\text { Tidak } \\
\text { Signifikan }\end{array}$ \\
$\begin{array}{c}\text { PAD Terhadap Belanja } \\
\text { Daerah }\end{array}$ & $-0,085$ & 0,933 & $\mathrm{H}_{0}$ diterima dan $\mathrm{H}_{1}$ ditolak & $\begin{array}{c}\text { Tidak } \\
\text { Signifikan }\end{array}$ \\
$\begin{array}{c}\text { DAU dan PAD terhadap } \\
\text { Belanja Daerah }\end{array}$ & 3,598 & 0,033 & $\mathrm{H}_{0}$ ditolak dan $\mathrm{H}_{1}$ diterima & Signifikan \\
\hline
\end{tabular}

Tabel 9 menunjukkan hasil perhitungan statistik uji $\mathrm{F}$ sebesar 3,598 dengan signifikansi 0,033 . Karena signifikannya jauh lebih besar dari 0,05 yang berarti secara simultan variabel independen DAU dan PAD berpengaruh secara signifikan terhadap variabel belanja daerah. Dengan demikian model regresi ini dapat menjelaskan DAU dan PAD berpengaruh terhadap Belanja Daerah.

Hasil Ha3 diterima karena nilai $\mathrm{F}$ hitungnya lebih lebih dari nilai $\mathrm{F}$ tabel, yaitu masing-masing sebesar 3,598 untuk F hitungnya sedangkan F tabelnya sebesar 3,032. Sehingga dapat diartikan bahwa terdapat pengaruh Dana Alokasi Umum dan Pendapatan Asli Daerah terhadap Belanja Daerah Pemerintah Kabupaten/Kota di Kalimantan Barat.

Hasil pengujian hipotesis menjelaskan bahwa DAU dan PAD secara berpengaruh terhadap Belanja Daerah di Kabupaten/Kota di Provinsi Kalimantan Barat. Sehingga dapat kita simpulkan bahwa semakin tinggi jumlah transfer pemerintah pusat dalam bentuk DAU maka akan dapat meningkatkan PAD pada daerah otonomi. Temuan ini memberikan indikasi adanya peningkatan pembiayaan daerah yang sangat tinggi. Peningkatan PAD yang tinggi, diimbangi pemerintah dengan melakukan alokasi belanja 
yang lebih tinggi, sehingga pada gilirannya pemerintah daerah bisa memperoleh transfer pemerintah pusat yang semakin tinggi.

Menentukan pengaruh masing-masing variabel independen terhadap variabel dependen dengan menggunakan uji t. Tabel 9 dapat menunjukkan hasil uji hipotesis secara parsial dari masing-masing variabel independen terhadap variabel dependen untuk melihat pengaruh dari setiap variabel independen terhadap variabel dependen yang mana pada penelitian ini adalah DAU dan PAD terhadap belanja daerah serta untuk melihat signifikan pengaruhnya dengan dilihat dari nilai beta yang menunjukkan bahwa nilainya lebih besar dari tingkat kepercayaan dalam penelitian ini.

\subsection{DAU Terhadap Belanja Daerah}

Untuk mengetahui hasil pengujian dari keputusan hipotesis maka diperlukan kriteria pengujian dengan melakukan perbandingan $-\mathrm{t}_{\text {statistik }}$ dengan $-\mathrm{t}_{\text {tabel }}$, dimana jika;

$-\mathrm{t}_{\text {statistik }}>-\mathrm{t}_{\text {tabel }}: \mathrm{H}_{0}$ diterima, $\mathrm{H}_{1}$ ditolak

$-\mathrm{t}_{\text {statistik }}<-\mathrm{t}_{\text {tabel }}: \mathrm{H}_{0}$ ditolak, $\mathrm{H}_{1}$ diterima

Dari kriteria pengujian tersebut maka hasil pengujian variabel Dana Alokasi Umum (DAU) terhadap Belanja Daerah yang memiliki hipotesis sebagai berikut :

$\mathrm{H}_{\mathrm{ol}}$ : Tidak terdapat pengaruh Dana Alokasi Umum terhadap Belanja Daerah Pemerintah Kabupaten/Kota di Kalimantan Barat

$\mathrm{H}_{\mathrm{al}} \quad$ : Terdapat pengaruh Dana Alokasi Umum terhadap Belanja Daerah Pemerintah Kabupaten/Kota di Kalimantan Barat

Nilai $-\mathrm{t}_{\text {statistik }}$ dari DAU terhadap Belanja Daerah sebesar -0,887 yang ternyata lebih besar dari - $t_{\text {tabel }}$ yang memiliki nilai sebesar -1,969. Jadi dapat ditarik keputusan bahwa $\mathrm{H}_{0} 1$ diterima dan $\mathrm{H}_{\mathrm{a} 1}$ ditolak karena $-\mathrm{t}_{\text {statistik }}<-\mathrm{t}_{\text {tabel }}$ yang masing- masing nilainya adalah $-0,887<-1,969 . \mathrm{H}_{\mathrm{a} 1}$ ini berarti secara parsial tidak terdapat pengaruh yang signifikan antara variabel DAU terhadap Belanja Daerah.

Hasil pengujian hipotesis menjelaskan bahwa DAU tidak berpengaruh terhadap Belanja Daerah di Kabupaten/Kota di Provinsi Kalimantan Barat. Pemerintahan Kabupaten/Kota masih tergantung oleh DAU dari Pemerintah Pusat ke Pemerintah Daerah dimaksudkan untuk menutup kesenjangan fiskal dan pemerataan kemampuan fiskal antar daerah dalam rangka membantu kemandirian pemerintah daerah menjalankan fungsi dan tugasnya melayani masyarakat. DAU merupakan sumber penerimaan daerah yang paling besar.

Pelimpahan kewenangan pada pemerintah daerah juga diikuti dengan pelimpahan dalam bidang keuangan. Pelimpahan dalam bidang keuangan mengakibatkan terjadinya perubahan-perubahan dalam struktur keuangan, diantaranya: (1) Penerimaan Daerah dari 
Dana Bagi Hasil, SDA dimaksudkan untuk meningkatkan penerimaan fiskal bagi daerah yang memiliki SDA seperti minyak, gas alam, hasil pertambangan, kehutanan, perkebunan, serta perikanan; (2) Penerimaan Daerah dari Bagi Hasil Pajak; (3) Skema bantuan pemerintah dalam bentuk transfer yakni DAU.

\subsection{PAD Terhadap Belanja Daerah}

Tabel 9 juga menunjukkan hasil pengujian dari keputusan hipotesis maka diperlukan kriteria pengujian dengan melakukan perbandingan $-t_{\text {statistik }}$ dengan $-t_{\text {tabel }}$, dimana jika:

$-\mathrm{t}_{\text {statistik }}>-\mathrm{t}_{\text {tabel }}: \mathrm{H}_{0}$ diterima, $\mathrm{H}_{1}$ ditolak

$-\mathrm{t}_{\text {statistik }}<-\mathrm{t}_{\text {tabel }}: \mathrm{H}_{0}$ ditolak, $\mathrm{H}_{1}$ diterima

Sedangkan pengujian untuk variabel PAD terhadap Belanja Daerah, memiliki hipotesis sebagai berikut :

$\mathrm{H}_{\mathrm{o} 2}$ : Tidak terdapat pengaruh Pendapatan Asli Daerah (PAD) terhadap Belanja Daerah Pemerintah Kabupaten/Kota di Kalimantan Barat

$\mathrm{H}_{\mathrm{a} 2}$ : Terdapat pengaruh Pendapatan Asli Daerah (PAD) terhadap Belanja Daerah Pemerintah Kabupaten/Kota di Kalimantan Barat

Nilai $-t_{\text {statistik }}$ dari Pendapatan Asli Daerah terhadap Belanja Daerah sebesar -0,085 yang ternyata lebih kecil dari $-t_{\text {tabel }}$ yang memiliki nilai sebesar $-1,989$. Jadi dapat ditarik keputusan bahwa $\mathrm{H}_{02}$ diterima dan $\mathrm{Ha}_{2}$ ditolak karena $-\mathrm{t}_{\text {statistik }}>-\mathrm{t}_{\text {tabel }}$ yang masingmasing nilainya adalah $-1,214>-1,989$. Hal ini berarti secara parsial tidak terdapat pengaruh secara signifikan antara variabel PAD terhadap Belanja Daerah.

Hasil pengujian hipotesis menjelaskan bahwa PAD tidak berpengaruh terhadap Belanja Daerah di Kabupaten/Kota di Provinsi Kalimantan Barat. PAD merupakan sumber pembiayaan untuk anggaran belanja daerah. PAD didapatkan dari iuran langsung dari masyarakat, seperti pajak, retribusi, dan lain sebagainya. Tanggung jawab agen (pemerintah daerah) kepada prinsipal (masyarakat) adalah memberikan pelayanan publik (public service) yang baik kepada masyarakat melalui anggaran belanja daerah, karena masyarakat telah memberikan sebagaian uangnya kepada pemerintah daerah.

Pertumbuhan belanja daerah merupakan salah satu usaha pemerintahan kabupaten/kota untuk mengoptimalkan potensi-potensi yang ada di daerah masingmasing. Pertumbuhan belanja daerah merupakan ciri positif bahwa pemerintahan Kabupaten/Kota telah berusaha mengurangi ketergantungan terhadap pemerintahan pusat. Dari hasil pengujian tersebut, maka Kabupaten/Kota di Provinsi Kalimantan Barat masih perlu untuk menggali potensi daerah dalam meningkatkan pertambahan pendapatan di daerah. Dalam era otonomi, daerah dituntut untuk mencari alternatif sumber pembiayaan pembangunan tanpa mengurangi harapan masih adanya bantuan dan 
bagian (sharing) dari pemerintah pusat dan mengunakan dana publik sesuai dengan prioritas dan aspirasi masyarakat (Mardiasmo, 2002).

\section{KESIMPULAN}

1) DAU dan PAD serta Belanja Daerah secara umum pada 14 Kabupaten/Kota di wilayah Provinsi Kalimantan Barat dalam periode tahun 2009 sampai dengan 2014 mengalami peningkatan dari tahun ke tahun.

2) Hasil pengujian hipotesis menjelaskan bahwa DAU dan PAD secara individu tidak berpengaruh terhadap Belanja Daerah di Kabupaten/Kota di Provinsi Kalimantan Barat. Pemerintahan Kabupaten/Kota masih tergantung oleh DAU dari Pemerintah Pusat ke Pemerintah Daerah. Ini dimaksudkan untuk menutup kesenjangan fiskal dan pemerataan kemampuan fiskal antar daerah dalam rangka membantu kemandirian pemerintah daerah menjalankan fungsi dan tugasnya melayani masyarakat. DAU merupakan sumber penerimaan daerah yang paling besar. Sedangkan PAD didapatkan dari iuran langsung masyarakat, seperti pajak, retribusi, dan lain sebagainya. Sehingga Kabupaten/Kota di Provinsi Kalimantan Barat masih perlu untuk menggali potensi daerah dalam meningkatkan pertambahan pendapatan di daerah.

\section{DAFTAR PUSTAKA}

Abdullah, S. \& Halim, A. (2003). Pengaruh Dana Alokasi Umum (DAU) dan Pendapatan Asli Daerah (PAD) terhadap Belanja Pemerintah Daerah: Studi Kasus Kabupaten/Kota Di Jawa dan Bali. Simposium Nasional Akuntansi VI:1140-1159. Surabaya 16-17 Oktober.

Arif, B. (2002). Akuntansi pemerintahan. Penerbit. Jakarta: Salemba Empat.

Bastian, I. (2002). Sistem Akuntansi Sektor Publik. Jakarta: Salemba Empat.

BPS. (2015). Kalimantan Barat Dalam Angka 2014. Pontianak: Badan Pusat Statistik Provinsi Kalimantan Barat.

Darise, N. (2008). Akuntansi Keuangan Daerah. Jakarta: PT. Indeks.

Darwanto \& Yustikasari, Y. (2007). Pengaruh pertumbuhan ekonomi, Pendapatan Asli Daerah, dan Dana Alokasi Umum terhadap pengalokasian anggaran belanja modal. Makalah disajikan pada Seminar Antarbangsa di Universitas Hassanudin, Makassar, 26-28 Juli. 
Ghozali, I. \& Sabeni, A. (1997). Pokok-pokok Akuntansi Pemerintahan. Edisi 4. Yogyakarta: BPFE.

Ghozali, I. (2006). Aplikasi Analisis Multivariat Dengan Program SPSS. Edisi 4. Semarang: Badan Penerbitan Universitas Diponegoro.

Halim, A. (2007). Akuntansi Sektor Publik : Akuntansi Keuangan Daerah. Edisi 3. Jakarta: Salemba Empat.

Isdijoso, B. (2002). Analisis Kebijakan Fiskal pada Era Otonomi Daerah (Studi Kasus: Sektor Pendidikan di Kota Surakarta). Kajian Ekonomi Dan Keuangan Vol.6 (1).

Kawedar, W., Rohman, A., \& Handayani, S. (2007). Akuntansi Sektor Publik: Pendekatan Penganggaran Daerah dan Akuntansi Keuangan Daerah. Semarang: UNDIP.

Keputusan Menteri Dalam Negeri No.29/2002 tentang Pedoman Pengurusan, Pertanggungjawaban dan Pengawasan Keuangan Daerah serta Tata Cara Penyusunan APBD, Pelaksana Tata Usaha Keuangan Daerah dan Penyusunan Perhitungan APBD.

Lembaran Negara Republik Indonesia. Undang-Undang Nomor 32 Tahun 2004 tentang Pemerintah Daerah.

Maemunah, M. (2006). Flypaper Effect pada Dana Alokasi Umum (DAU) dan Pendapatan Asli Daerah (PAD) terhadap Belanja Daerah pada Kabupaten/Kota di Pulau Sumatera. Simposium Nasional Akuntansi IX. Padang.

Mardiasmo. (2002). Otonomi dan Manajemen keuangan daerah. Yogyakarta: Andi.

Peraturan Pemerintah Republik Indonesia Nomor 24 Tahun 2005 tentang Standar Akuntansi Pemerintahan.

Peraturan Pemerintah Republik Indonesia Nomor 58 Tahun 2005 tentang Pengelolaan Keuangan Daerah.

Prakosa, B. (2004). Pengaruh Dana Pengaruh Dana Alokasi Umum (DAU) Dan Pendapatan Asli Daerah (PAD) terhadap Belanja Daerah. Fakultas Ekonomi UII: Yogyakarta.

Pratiwi, N. (2007). Pengaruh Dana Alokasi Umum (DAU) dan Pendapatan Asli Daerah (PAD) Terhadap Prediksi Belanja Daerah Pada Kabupaten/Kota di Indonesia. Skripsi Sarjana (dipublikasikan). Fakultas Ekonomi UII: Yogyakarta.

Puspita. S., Noni \& Yahya, I. (2009). Pengaruh Dana Alokasi Umum (DAU) dan Pendaptan Asli Daerah (PAD) terhadap Belanja Langsung. Universitas Sumatera Utara, Medan. 
Realisasi APBD Tahun 2012-2015. Provinsi Kalimantan Barat. Diakses dari http://www.bpkp.go.id.

Safitri, N. A. (2008). Analisis Kinerja Anggaran Satuan Kerja Perangkat Daerah (SKPD) Sebelum dan Sesudah Pemberlakuan Pemendagri Nomor 13 Tahun 2006 Studi Pada Pemerintah Kabupaten Kudus. Skripsi Sarjana (Tidak dipublikasikan). Fakultas Ekonomi UNDIP: Semarang.

Sekaran, U. (2002). Research Method for Business : A skill Building Approach, $7^{\text {th }}$ Edition, New York: John Wiley and Sons.

Singgih, S. (2000). Buku Latihan SPSS Statistik Parametrik. Jakarta: Elex Media Komputindo.

Triwidodo, P. (2007). Flypaper Effect pada Dana Alokasi Umum (DAU) dan Pendapatan Asli Daerah (PAD) terhadap Belanja Daerah pada Kabupaten/Kota di Bali. Skripsi Sarjana (dipublikasikan). Fakultas Ekonomi UII: Yogyakarta.

Undang-Undang Nomor 33 Tahun 2004 tentang Perimbangan Keuangan Pemerintah Pusat dan Daerah. 